\title{
Effects of Soil-Like Materials Mix from Drill Cuttings, Sewage Sludge and Sawdust on the Growth of Trifolium pratense L. and Transfer of Heavy Metals
}

\author{
Justyna Kujawska ${ }^{1 *}$, Małgorzata Pawłowska ${ }^{1 *}$ \\ 1 Institute of Renewable Energy Engineering, Faculty of Environmental Engineering, Lublin University of \\ Technology, 40B Nadbystrzycka Street, Lublin 20-618, Poland \\ * Corresponding author's e-mail: j.kujawska@pollub.pl
}

\begin{abstract}
Approximately 80000 tons of drilling waste is produced in Poland annually. This type of waste is relocated and deposited in waste neutralization plants or landfills. Eventually, it must be managed. Reuse of solid wastes might constitute a method of their utilization. The article investigates the use of drill cuttings, sewage sludge and sawdust for production of soil-like mixtures. The studies on evaluation of the possibility of economic application of soillike materials were carried out. The assessment was conducted on the basis of metal content in soil-like materials and plants cultivated on substrates produced of soil-like materials. In accordance with the valid legal regulations, the concentration of metals in soil-like materials enables their application on class II soils, i.e. arable land. The concentration of heavy metals in the plants cultivated on the substrates produced with soil-like materials is low and does not exceed the concentration of metals determined in animal feeding standards.
\end{abstract}

Keywords: drill cuttings, wastes, landfarming, recultivation

\section{INTRODUCTION}

The total production of wastes in Europe approximates 3 billion tons. Only about $40 \%$ of this amount was recycled, and the rest was deposited or combusted [Woodard and Curran 2006]. Reuse is the key element of waste management. The most natural direction for municipal waste and sewage sludge management is composting. The produced compost is used as a fertilizer, improving the soil properties [Boruszko 2011]. Low nutritional value of compost along with low mineralization may result in increased requirement of compost in order to satisfy their nitrogen and phosphorus uptake [Cambardella 2003]. There are studies in which mineral wastes are added in order to increase the amount of mineral compounds in compost [Belyaeva 2010, Zmora-Nahum et al. 2007]. The resultant soil-like materials can be utilized in land application.

In recent years the amount of drilling wastes in Poland has increased due to the exploration of new deposits of conventional and non-con- ventional hydrocarbons [Macuda 2017]. Part of the mining wastes is stabilized, e.g. by means of cement or calcium hydroxide and finds application in road construction. However, over $70 \%$ is deposited in waste neutralization plants [Leonard et al. 2010]. Drilling wastes - cuttings, i.e. the excavated material with spent drilling fluid produced in the process of drilling. They are characterized by a high content of such elements as: calcium, magnesium, potassium, sodium. The $\mathrm{pH}$ of drilling wastes exceeds 10 , which indicates the possibility of neutralizing acidic soils [Abbe 2009]. Drilling wastes could be introduced to degraded soils. There are studies [Zha et al., Zvomuya et al. 2011, Chaineau 1996] indicating that the addition of drilling wastes improves the sorption properties of soil and the composition of soil complex. However, the Polish legal system, in contrast to the American, prohibits the direct introduction of drilling wastes to soil [Regulation of the Minister of Environment of $20^{\text {th }}$ January 2015 on the recovery process of R10 [Journal of Laws 2015, item 132]. 
Creation of a soil-like material from drill cuttings, compost and sawdust was proposed in the paper. The physical and chemical properties of these components indicate that the resulting mixture may improve the soil properties. There are concerns that the high content of heavy metals both in compost as well as drilling wastes may infiltrate to ground waters, soils, and plants. The bioavailability of metals for plants is the main method for the assessment of heavy metals toxicity.

The article contains an assessment pertaining to the feasibility of economic application of the soil-like material. The assessment was conducted on the basis of the metal content in the produced soil-like materials and plants cultivated on the substrates.

\section{MATERIALS AND METHODS}

The following components were used for the production of soil-like materials:

- compost from the organic municipal waste fraction, produced in a composting plant located on the premises of Wilcze Doły landfill in Kraśnik,

- drill cuttings collected from the layer of waste deposited in a reclaimed object in Luchów Górny, Tarnogród commune,

- sawdust from a sawmill located in Luchów Górny, Tarnogród commune,

The above-mentioned materials were mixed in various weight ratios, yielding four mixture in the proportions presented in Table 1 .

Determination of physicochemical properties:

- Electrical conductivity - in the slurry (soil weight : volume 1:2.5) with conductometric titration (by means of a VERSA STAR meter manufactured by ORION);

- $\mathrm{pH}$ value by means of potentiometric method in water solution and in $1 \mathrm{M}$ solution of potassium chloride (PN-ISO 10390: 1997P soil quality. Determination of $\mathrm{pH}$ ),

Table 1. Compost, drill cuttings and sawdust treatments used in the experiments.

\begin{tabular}{|c|c|c|c|}
\hline \multirow{2}{*}{$\begin{array}{c}\text { Soil-like } \\
\text { mixtures }\end{array}$} & Compost & Drill cuttings & Sawdust \\
\cline { 2 - 4 } & \multicolumn{3}{|c|}{ [\% weight] } \\
\hline A12 & 72.5 & 2.5 & 25 \\
\hline A13 & 45 & 5 & 50 \\
\hline A14 & 40 & 10 & 50 \\
\hline A15 & 60 & 15 & 25 \\
\hline
\end{tabular}

- dry matter content by means of loss on drying method in the temperature of $105^{\circ} \mathrm{C}$ (PN EN ISO 11465:1999P soil quality. Determination of dry matter content of soil and water in soil per dry mass of soil. Gravimetric method),

- total exchangeable bases (S) by Pallmann method in $0.5 \mathrm{~mol} / \mathrm{dm} 3 \mathrm{NH} 4 \mathrm{Cl}$ at $\mathrm{pH} 8.2$,

- carbonate content was determined with Scheibler's volumetric method,

- total organic carbon by means of TOC-5050A analyzer Schimadzu (PN-ISO 4335 standard),

- total nitrogen content by Kjeldhal method using 1002 Kjeltech distillation unit

- total heavy metals were determined by ICP-OES Ultrace 238 (Jobin Yvon-Horriba France) using direct calibration method after microwave digestion (Multiwave 3000, Anton Paar). The samples of homogenized soil $(1 \mathrm{~g})$ were digested in acid mixture of HNO3: $\mathrm{HCl}(5: 2)$ and water samples (15 g) were digested in $\mathrm{HNO} 3(3 \mathrm{~mL})$. The digestion process lasted $45 \mathrm{~min}$ at $180^{\circ} \mathrm{C}$ and at the pressure of 18 bars. Metal concentrations were determined at different wavelengths $(213-395 \mathrm{~nm})$. Detection limits for particular metals did not exceed $10 \mathrm{ppb}$.

Greenhouse experiment: The studies were conducted using clover seeds (Trifolium pratense L.). Twelve pots ( $350 \mathrm{ml}$ each) were prepared and divided into 4 series (each in triplicate):

12 seeds of wheat, originating from the same source, were sown. The plants were watered with distilled water until they reached $75 \%$ of total water capacity. The cultivation was carried out in accordance with PN-EN ISO 11269-2:2013-06 standard.

The collected plants were separated into roots and stalks. The biomass of plant roots and shoots obtained in each series was weighed. The cleaned plant material from each pot was dried in $70^{\circ} \mathrm{C}$ and ground in laboratory ball mill. The content of $\mathrm{Ba}, \mathrm{Cd}, \mathrm{Cr}, \mathrm{Cu}, \mathrm{Ni}, \mathrm{Pb}, \mathrm{Zn}$ was determined in the plant material, following its mineralization in nitrogen and hydrochloric acid (5:2) performed by means of Microwave 3000 by Anton Paar. The elements were indicated using mass spectrometry method with inductively coupled plasma by means of ICP-OES JY 238 Ultrace (Jobin YvonHorriba, France). On the basis of the obtained metal contents in plant biomass, bioaccumulation factor was calculated using the formula: 


$$
\mathrm{BCF}=\mathrm{C}_{\mathrm{P}} / \mathrm{C}_{\mathrm{G}}
$$

where: $C_{P}$-concentration of metals in the surface/ underground parts of the plant, $\mathrm{mg} / \mathrm{kg}$; $C_{G}$ - concentration of metal in soil at the beginning of the process, $\mathrm{mg} / \mathrm{kg}$.

Mean values with standard deviation were calculated for the results of this study. Then, the statistical analyses based on the one-way analysis of variance (ANOVA) and multiple T-Tukey tests with the significance level $\alpha=0.05$ were carried out. T-Tukey's multiple comparative tests provided a detailed comparative analysis of mean values by isolating statistically homogeneous groups (homogeneous groups). The matrix of correlation coefficients between the variables was determined.

\section{RESULTS AND DISCUSSION}

There are studies which confirm the positive influence of drilling wastes on lightweight soils [Zha et al. 2017]. The research conducted by Kominko et al. on short- and mid-term results of various organic fertilizers such as: sewage sludge, municipal wastes and manure on the physical properties of soil showed that composting of solid wastes and introducing sewage sludge to soil improves its stability [Kominko et al. 2017].

Table 2 presents the selected physicochemical properties of soil-like mixtures. The mixtures are characterized by neutral $\mathrm{pH}$. The highest value of $\mathrm{pH}$ - over 6.9 - was obtained by $\mathrm{A} 12$ and A15 mixtures, which is a statistically significant difference from the $\mathrm{pH}$ of $\mathrm{A} 13$ and $\mathrm{A} 14$ mixtures. This $\mathrm{pH}$ is optimal for the growth of majority of arable crops.

The content of carbonates increases along with the content of drill cuttings in mixtures. Drill cuttings are characterized by high carbonate content. The studies carried out by Gonet et al. also indicated that the addition of drilling wastes greatly increased the content of carbonates in the soil with drilling waste addition [Gonet et al., 2006] The contents of carbonates in mixtures are statistically significantly different.

A similar situation occurs with the value of total exchangeable bases. Total exchangeable bases in soil-like materials are statistically significantly different. The research conducted by Gonet indicates that the addition of drilling wastes greatly changes the total exchangeable bases with the addition of drilling wastes [Gonet et al. 2006].

The value of nitrogen in soil-like materials amounted to about $1 \%$. The addition of drilling fluid reduced the nitrogen content in the produced mixtures. The content of nitrogen in the compost approximates 1.5\% [Belayaeva 2011]. Drill cuttings contain a very small amount of nitrogen [Zvomuya et al. 2011]. The contents of nitrogen in A12 and A13 mixtures are statistically significantly different from A14 and A15. The concentration of nitrogen in Polish soils ranges from 0.1 to $0.3 \%$ [Kabata-Pendias et al. 2015]. The produced materials are characterized by the content of about $1 \%$.

The mixtures contain roughly $20 \%$ of carbon. The content of carbon in mixtures is not statistically significantly different.

The C:N ratio in materials reaches about 20. The optimal value of $\mathrm{C}: \mathrm{N}$ for plant growth is assumed as 23 (Ozimek A. et al. 2012). The $\mathrm{C}: \mathrm{N}$ ratio greater than 30 indicates low activity of biological processes and accumulation of undecomposed organic substance (Mroczkowski et al. 2016).

The organic matter content exceeds $30 \%$; this value is 5 times greater than the maximum value of organic matter found in Polish soils [Report OSCR 2012]. On the basis of organic matter content (Table 2), in line with PN-EN ISO 14688-2 standard, the mixtures may be considered as highly organic soils $(>30 \%)$.

Organic matter plays an important role in maintaining the soil quality. It improves the structure of soil, may increase the infiltration rate and reduce the soil erosion [Rattan 2016]. Such high

Table 2. Physicochemical properties of artificial soil

\begin{tabular}{|c|c|c|c|c|c|c|}
\hline Artificial soil & $\mathrm{pH}$ & $\mathrm{OM}[\%]$ & $\mathrm{CaCO}_{3}[\%]$ & $\mathrm{N}[\%]$ & $\mathrm{C}[\%]$ & $\mathrm{S}[\mathrm{mmol}]$ \\
\hline $\mathrm{A} 12$ & $6.94^{\mathrm{a}}$ & $33.97^{\mathrm{a}}$ & $1.16^{\mathrm{a}}$ & $1.13^{\mathrm{a}}$ & $19.75^{\mathrm{a}}$ & $30^{\mathrm{a}}$ \\
\hline $\mathrm{A} 13$ & $6.38^{\mathrm{b}}$ & $35.69^{\mathrm{a}}$ & $1.63^{\mathrm{b}}$ & $1.08^{\mathrm{a}}$ & $20.75^{\mathrm{a}}$ & $32.03^{\mathrm{b}}$ \\
\hline $\mathrm{A} 14$ & $6.46^{\mathrm{c}}$ & $34.04^{\mathrm{a}}$ & $1.78^{\mathrm{c}}$ & $0.77^{\mathrm{b}}$ & $19.79^{\mathrm{a}}$ & $33.37^{\mathrm{c}}$ \\
\hline $\mathrm{A} 15$ & $6.98^{\mathrm{a}}$ & $33.2^{\mathrm{a}}$ & $2.21^{\mathrm{d}}$ & $0.77^{\mathrm{b}}$ & $19.30^{\mathrm{a}}$ & $34.67^{\mathrm{d}}$ \\
\hline
\end{tabular}

The superscript ${ }^{\text {a }}$ next to the average content values in the Table (Tukey Homogeneous Groups) indicates statistically homogeneous groups. The presence of the indicator designates the lack of statistically significant difference between them. 
Table 3. The concentration of heavy metals in artificial soils ( $\mathrm{mg} / \mathrm{kg})$.

\begin{tabular}{|c|c|c|c|c|c|c|c|}
\hline Artificial soil $[\mathrm{mg} / \mathrm{kg}]$ & $\mathrm{Ba}$ & $\mathrm{Cd}$ & $\mathrm{Cr}$ & $\mathrm{Cu}$ & $\mathrm{Ni}$ & $\mathrm{Pb}$ & $\mathrm{Zn}$ \\
\hline $\mathrm{A} 12$ & $304.20^{\mathrm{c}}$ & $0.12^{\mathrm{a}}$ & $3.29^{\mathrm{a}}$ & $0.59^{\mathrm{a}}$ & $0,59^{\mathrm{a}}$ & $7,17^{\mathrm{a}}$ & $34,05^{\mathrm{b}}$ \\
\hline $\mathrm{A} 13$ & $325.39^{\mathrm{a}}$ & $0.11^{\mathrm{a}}$ & $4.39^{\mathrm{b}}$ & $1.44^{\mathrm{b}}$ & $1,44^{\mathrm{b}}$ & $7,55^{\mathrm{a}}$ & $47,99^{\mathrm{a}}$ \\
\hline $\mathrm{A} 14$ & $340.36^{\mathrm{a}}$ & $0.23^{\mathrm{b}}$ & $6.73^{\mathrm{d}}$ & $3.72^{\mathrm{c}}$ & $2,48^{\mathrm{d}}$ & $7,51^{\mathrm{a}}$ & $89,98^{\mathrm{d}}$ \\
\hline $\mathrm{A} 15$ & $382.81^{\mathrm{b}}$ & $0.28^{\mathrm{b}}$ & $7.53^{\mathrm{c}}$ & $7.43^{\mathrm{d}}$ & $3,72^{\mathrm{c}}$ & $8,56^{\mathrm{b}}$ & $99,75^{\mathrm{c}}$ \\
\hline & 400 & 2 & 200 & 200 & 150 & 200 & 500 \\
\hline
\end{tabular}

The superscript a next to the average content values in the Table (Tukey Homogeneous Groups) indicates statistically homogeneous groups. The presence of the indicator designates the lack of statistically significant difference between them.

organic matter content may limit the availability of heavy metals in the produced soil-like materials.

The concentration of heavy metals in soil-like materials was presented in Table 4. Along with the increase in the percentage content of drill cuttings, the concentration of heavy metals increases as well. However, the concentrations of heavy metals in all mixtures are lower than the ones stated in the Regulation of the Minister of Environment of $1^{\text {st }}$ September 2016 on the conduct of the assessment of contamination of the surface of the earth (Journal of Laws, 2016, item 1395). Therefore, the threat resulting from the application of soil-like materials on the environmental pollution may be controlled by creating waste mixtures in appropriate ratios. The content of metals enables the application of waste components for class II soils, i.e. agricultural soils.

The concentration of barium in the created soil-like materials is approximately 3 times greater than the maximum concentration of barium in Polish soils, reaching approximately $100 \mathrm{mg} /$ $\mathrm{kg}$ [Report OSCR 2012]. The highest concentration of barium, reaching $382.81 \mathrm{mgBa} / \mathrm{kg}$ was obtained for A15 mixture, which is statistically significantly different from the concentration of barium in other soil-like materials. Despite such high concentration of barium, its value does not exceed the permissible levels stated in the Polish law; moreover, barium is hardly soluble in water, does not infiltrate to ground waters and is not taken up by plants [Kabata-Pendias et al. 2001]. The created mixtures are characterized by lower concentration of cadmium than the average cadmium concentration in Polish soils, amounting to $0.59 \mathrm{mgCd} / \mathrm{kg}$ [Czech T. 2012]. In relation to $\mathrm{A} 12$ and $\mathrm{A} 13$, the content of cadmium in A14 and A15 mixtures is twice as high, which is statistically significant.

The highest concentration of lead, i.e. $8.56 \mathrm{mgPb} / \mathrm{kg}$ was achieved with A15 soil-like material. This is statistically significantly different from the concentration of lead in other soillike materials, but lower than the average content of lead in Polish soils, amounting to about 23.3 $\mathrm{mgPb} / \mathrm{kg}$ [Czech T. 2012].

The average concentrations of chromium in Polish soils approximate $11.3 \mathrm{mgCr} / \mathrm{kg}$, copper $9.9 \mathrm{mgCu} / \mathrm{kg}$, nickel $9.4 \mathrm{mgNi} / \mathrm{kg}$, zinc 78.8 $\mathrm{mgZn} / \mathrm{kg}$ [Report OSCR 2012]. The concentrations of these elements in the produced mixtures are lower. The concentrations of chromium, copper, nickel, nickel, zinc in particular soil-like materials are statistically significantly different.

The biomass of clover cultivated on soil-like mixtures is presented in Figure 1. Along with the increase of drill cuttings content in soil-like materials, the biomass is reduced. The same results were obtained by Gonet [Gonet et al. 2006 ]. The decrease in biomass results from the increased

Table 4. The concentration of heavy metals in Trifolium pratense L. (mg/kg).

\begin{tabular}{|c|c|c|c|c|c|c|c|}
\hline Artificial soil $[\mathrm{mg} / \mathrm{kg}]$ & $\mathrm{Ba}$ & $\mathrm{Cd}$ & $\mathrm{Cr}$ & $\mathrm{Cu}$ & $\mathrm{Ni}$ & $\mathrm{Pb}$ & $\mathrm{Zn}$ \\
\hline A 12 shoot & $48.54^{\mathrm{a}}$ & $0.15^{\mathrm{c}}$ & $1.42^{\mathrm{a}}$ & $8.63^{\mathrm{a}}$ & $2.23^{\mathrm{a}}$ & $0.82^{\mathrm{a}}$ & $403.02^{\mathrm{a}}$ \\
\hline A13 shoot & $49.76^{\mathrm{a}}$ & $0.14^{\mathrm{c}}$ & $2.07^{\mathrm{a}}$ & $8.87^{\mathrm{a}}$ & $2.77^{\mathrm{a}, \mathrm{c}}$ & $1.01^{\mathrm{a}}$ & $405.44^{\mathrm{a}}$ \\
\hline A 14 shoot & $46.73^{\mathrm{a}}$ & $0.21^{\mathrm{a}}$ & $2.95^{\mathrm{b}}$ & $8.47^{\mathrm{a}}$ & $2.59^{\mathrm{c}}$ & $1.85^{\mathrm{a}}$ & $445.39^{\mathrm{a}}$ \\
\hline A 15 shoot & $48.33^{\mathrm{a}}$ & $0.34^{\mathrm{a}}$ & $5.11^{\mathrm{c}}$ & $8.28^{\mathrm{a}}$ & $3.64^{\mathrm{d}}$ & $1.93^{\mathrm{a}}$ & $489.54^{\mathrm{a}}$ \\
\hline & & 0.5 & 20 & 30 & 10 & 10 & 100 \\
\hline
\end{tabular}

The superscript a next to the average content values in the Table (Tukey Homogeneous Groups) indicates statistically homogeneous groups. The presence of the indicator designates the lack of statistically significant difference between them. 
content of mineral salts. The highest biomass was found in the plants cultivated on A12 mixture. The biomass values obtained on particular substrates do not differ in a statistically significant way.

The content of heavy metals accumulated in clover was investigated, because it has a major influence on the possibility of assessing the feasibility of utilizing the produced soil-like materials for agricultural purposes. There are works in which a significant increase of metal content was observed in the plants cultivated on compost [Belyaeva et al., 2009, Zmora-Nahum et al. 2007] or drill cuttings with the addition of soil [Gonet 2006, Zvomuya 2011]. The content of metals in the plants cultivated on soil-like materials is low and does not exceed the permissible concentrations of heavy metals in feed, determined by Kabata-Pendias et al. and the Regulation of the Minister of Agriculture and Rural Development of $23^{\text {rd }}$ January 2007 on the permissible concentrations of undesirable substances in feed [Kabata-Pendias et al. 2001].

The reference values of metals in plants equal: $0.05 \mathrm{mgCd} \cdot \mathrm{kg}^{-1}, 1.5 \mathrm{mgCr} \cdot \mathrm{kg}^{-1}, 10 \mathrm{mgCu} \cdot \mathrm{kg}^{-1}$, $1.5 \mathrm{mgNi} \cdot \mathrm{kg}^{-1}, 1 \mathrm{mgPb} \cdot \mathrm{kg}^{-1}, 50 \mathrm{mgZn} \cdot \mathrm{kg}^{-1}$, respectively [Market 1992]. The concentrations of all the considered metals in the plants cultivated on soil-like materials are higher than the reference values.

The concentration of chromium in the plants cultivated on A12 soil-like material is approximately three times greater than in the plants cultivated on A12 soil-like material, which is statistically significant. The concentration of cadmium in the plants cultivated on A15 substrate is twice as high as the one of the plants frown on A12 substrate, which too is significant. The concentrations of barium, copper, lead and zinc in the plants cultivated on particular substrates are not statistically significantly different.

Metals from substrates may be transported to plants. The heavy metal accumulation capacity of plants can be expressed by means of the bioconcentration factor $(\mathrm{BCF})$ which was presented in Table 5. The BCF values were below 1 , except for $\mathrm{Ni}, \mathrm{Cu}$, and $\mathrm{Zn}$. The $\mathrm{BFC}$ for $\mathrm{Ni}, \mathrm{Cu}$, and $\mathrm{Zn}$

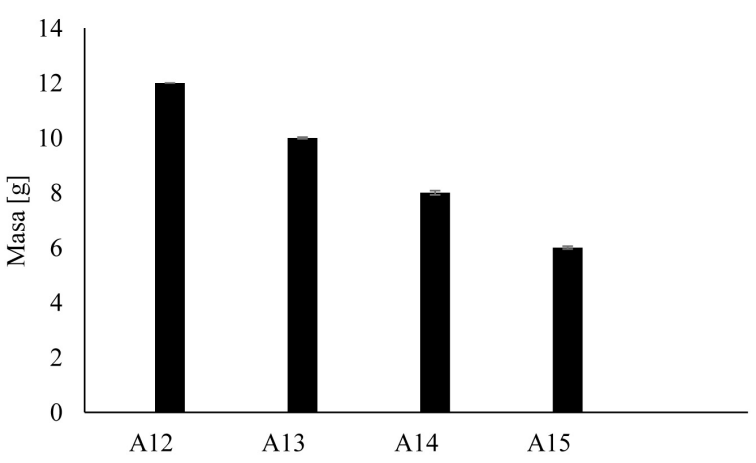

Fig 1. Biomass of Trifolium pratense L. cultivated on soil-like materials.

in the surface part, in all mixtures, exceeded 1, which indicates that clover easily accumulates these compounds.

The results presented in table 5 depict this discrepancy in the BFC values and heavy metal absorption in plants, which can be related to the changes in the application doses of drill cuttings and composts.

\section{CONCLUSIONS}

1. The proposal of producing soil-like mixtures from such materials as compost, sawdust, and drill cuttings may become an alternative method of their management.

2 . The soil-like mixtures are highly organic materials. $\mathrm{pH}$ and ratio $\mathrm{C} / \mathrm{N}$ the soil-like mixtures are optimal for the growth of majority of arable crops.

3. The presented results indicate that the content of heavy metals in the produced soil-like materials is characterized by limited bio-availability for the environment. However, the long-term impact of soil-like mixtures was not studied.

4. The biomass of clover cultivated on soil-like mixtures is reduced along with the increase of drill cuttings content in soil-like materials. The plants cultivated on soil-like materials can be used as feed. The clover easily accumulates $\mathrm{Cu}, \mathrm{Ni}, \mathrm{Zn}$.

Table 5 . BCFs of heavy metals in Trifolium pratense L.

\begin{tabular}{|c|c|c|c|c|c|c|c|}
\hline \multirow{2}{*}{ Mixture } & \multicolumn{7}{|c|}{ BCF } \\
\cline { 2 - 9 } & $\mathrm{Ba}$ & $\mathrm{Cd}$ & $\mathrm{Cr}$ & $\mathrm{Cu}$ & $\mathrm{Ni}$ & $\mathrm{Pb}$ & $\mathrm{Zn}$ \\
\hline $\mathrm{A} 12$ & 0.11 & 0.15 & 0.48 & 1.21 & 1.27 & 0.29 & 1.10 \\
\hline $\mathrm{A} 13$ & 0.10 & 0.13 & 0.41 & 1.61 & 1.81 & 0.59 & 1.11 \\
\hline A14 & 0.15 & 0.21 & 0.39 & 1.44 & 1.43 & 0.27 & 1.20 \\
\hline A15 & 0.15 & 0.34 & 0.75 & 1.89 & 1.98 & 0.40 & 1.20 \\
\hline
\end{tabular}




\section{Acknowledgements}

This study was supported by the Polish Ministry of Science \& Higher Education's Research Project no. BLUE GAS-BG1/SOIL/2013, which was carried out as a part of joint program between the National Center for Research \& Development and the Industrial Development Agency JSC.

\section{REFERENCES}

1. Abbe E.O., Grimes M.S, Fowler D.G., Boccaccini R.A. 2009. Novel sintered glass - ceramics from vertified oil well drill cuttings. Journal Material Science, 60 (1), 4296-4302.

2. Bazrafshan E., Zarei A., Kord M.F., Poormollae N., Mahmoodi S., Zazouli M.A. 2015. Maturity and Stability Evaluation of Composted Municipal Solid Wastes. Health Scope, 5(1), e33202-33206.

3. Belyaeva O.N., Haynes R.J. 2009. Chemical, microbial and physical poperties of manufactured soils produced by co-composting municipal green waste with coal fly ash. Bioresorce Technology, 100, 5203-5209

4. Boruszko D. 2011. Research and Evaluation of Fertilizing Value of Composts and Vermicomposts. Annual Set The Environmental Protection/Rocznik Ochrona Środowiska (In Polish), 13, 1417-1428.

5. Cambardellaa C.A., Richardb T.L., Russella A. 2003. Compost mineralization in soil as a function of composting process conditions. European Journal of Soil Biology, 39(3), 117-127.

6. Chaineau C.H., Morel J.L., Oudot J. 1996, Land treatment of oil - based drill cuttings in an agricultural soil. Journal of Environmental Quality, 25(4), 858-867.

7. Czech T., Baran A., Wieczorek J. 2014. Content of heavy metals in soil and plants from an area Borzęcin Municipality (Malopolska Province) (In Polish). Journal of Ecological Engineering, 37, 89-98.

8. Gonet A., 2006. Elaboration of a method of organic-mineral drilling waste processing in the aspect of its management (In Polish). Faculty of Drilling, Oil and Gas, AGH, UST Cracow.

9. Kabata-Pendias A. and Szteke B. 2015. Trace elements in abiotic and biotic environments, CRC Press USA.
10. Kabata-Pendias A. and Pendias H. 2001. Trace elements in soils and plants, 3rd ed. CRC Press USA.

11. Kominko H., Gorazda K., Wzorek Z. 2017. The possibility of organo-mineral fertilizer production from sewage sludge. Waste and Biomass Valorization, 8(5), 1781-1791.

12. Leonard S.A., Stegmann J.A. 2010. Stabilization/ solidification of petroleum drill cuttings. Journal of Hazardous Materials, 174, 463-472.

13. Macuda J., Bogacki M., Siemek J. 2017. Effect of drilling for shale gas on the quality of atmospheric air. Problems of Sustainable Development, 12(1), 91-100.

14. Market B. 1992. Establishing of 'reference plant' for inorganic characterization of different plant species by chemical fingerprinting. Water, Air, and Soil Pollution, 64, 533-538.

15. Mroczkowski W., Stuczyński T. 2016. Determination of total nitrogen in soils. Techniques and methods (In Polish), 2, 23-24.

16. Ozimek A., Kopeć M. 2012. Assessment of biological activity of biomass at different stages of composting process with use of the oxitop control measurement system. Acta Agrophysica (In Polish), 19(2), 379-390.

17. Report OSCR in Rzeszow. 2012. http://www. sokolow-mlp.pl/e107_files/downloads/Raport_o_ stanie_gleb_2011.pdf date 18.06.2017 (In Polish).

18. Rattan L. 2016. Encyclopedia of Soil Science. London: CRC Press Taylor \& Francis.

19. Woodard B and Curran I. 2006. Industrial Waste Treatment Handbook. Elsevier and Science Technology.

20. Zhaa X., Liaoa X., Zhaoa X., Liua F., Heb A.Q., Xiongca W.X. 2017. Turning waste drilling fluids into a new, sustainable soil resources for landscaping. Ecological Engineering, in press.

21. Zmora-Nahum S., Hadar Y., Chen Y. 2007. Physico-chemical properties of commercial compost varying in their source materials and country of origin. Soli Biology \& Biochemistry 39, 1263-1276

22. Zvomuya F., Larney F.J., Willms W.D., Beck R.K., Olson A.F. 2011. Vegetation response to a one-time spent drilling mud application to semiarid, mixedgrass prairie. Rangeland Ecology Manage, 64, 375-383. 